\title{
Awareness and Knowledge of Hepatitis B and HIV/AIDS, Among the University of Kassala Students, Sudan
}

\section{Fatima A. Khalid ${ }^{1 *}$, Amna A. Eltayeb ${ }^{2}$ and NourEldaim E. Elbadawi ${ }^{3}$}

${ }^{1}$ Tuberculosis Research Center, Faculty of Medicine and Health Sciences, University of Kassala, Kassala State, Sudan ${ }^{2}$ Department of Nursing program, Faculty of Medicine and Health Sciences, University of Kassala, Kassala State, Sudan ${ }^{3}$ Department of Biochemistry, Faculty of Medicine and Health Sciences, University of Kassala, Kassala State, Sudan

\begin{abstract}
Background: Hepatitis B and AIDS are major health problems worldwide. The number of infected people is liable to increase. Both diseases run chronic courses causing a financial drain of family sources. Awareness towards prevention and control of these diseases is necessary among both educated and illiterate people. This study aimed to assess the University of Kassala students' knowledge and awareness of the infectious nature of the two diseases.
\end{abstract}

Method: A cross-sectional study was conducted among the students of the University of Kassala, Kassala State, Sudan. The study was held from April through July 2011. Data was collected through self administered questionnaire and analyzed by using SPSS version (16.0).

Findings: A total of 395 students has responded to the study, and completed a questionnaire on knowledge and awareness about hepatitis B and AIDS. Among these, $185(46.8 \%)$ were males and $210(53.2 \%)$ were females with ages ranging from 17 to 35 years (mean: $20.45 \pm 2.89$ ). The overall study revealed that, there was a weakness in general knowledge about viral diseases (AIDS and HBV) among students. Regarding AIDS, the students were knowledgeable about the communicability, infectious nature and transmission modes, but misconception was observed about symptoms and preventive measures. Concerning HBV viral infection, the students showed poor knowledge on causative agents, mode of transmission, symptoms and prevention. A significant difference was found between the students' knowledge of AIDS and HBV concerning the routes of transmission ( $P=0.009)$, symptoms $(P=0.000)$ and prevention measures $(P=0.000)$. These findings may be attributed to absence of formal school based health education in our country which may be the main reason for the poor knowledge of viral diseases including AIDS and hepatitis $B$.

Conclusion: This study showed that the students had poor knowledge and awareness, particularly about HBV compared to AIDS. As students play a pivotal role in dissemination of knowledge and raising awareness among their families and communities, more efforts should be exerted to develop the two parameters, particularly among the students of non- medical profession in order to limit the hazardous effects of such diseases.

Keywords: Infectious diseases; HIV; HBV; Knowledge; Students; Sudan

Abbreviation: HIV: Human Immunodeficiency Virus; AIDS: Acquired Immunodeficiency Syndrome; HBV: Hepatitis B Virus

\section{Introduction}

Hepatitis B and human immunodeficiency virus (HIV) viral infections are serious global public health problems. Worldwide, two billion people are infected with $\mathrm{HBV}$, and an estimated of 370 million chronic infections, affecting 5-7\% of the world's population [1]. 600.000 persons die each year due to acute or chronic consequences of HBV [2]. Forty million people are living with HIV. About two million of these died of AIDS, and 2.7 million people were newly infected with the virus worldwide [3-5]. Among the HIV- infected persons, about 4 million have chronic HBV co-infection [1]. Both AIDS and HBV shared common routes of transmission including unsafe sexual practices, blood borne transmission and sharing of infected needles or syringes [6-9].

Sudan is one of the most severely affected countries with HBV and HIV. Estimated number of people living with HIV was 260,000, most of them above the age of 15 years. The death rate due to AIDS was estimated at 12,000 [3]. There are regional variations in the prevalence of HIV infection with higher prevalence in Eastern states, Khartoum state and White Nile state [10]. The prevalence of HIV among university students in Sudan was $1.1 \%$.

Continual transmission of these diseases could be attributed to a bundle of reasons including: missing of opportunities for prevention, lack of awareness about their prevalence and prevention (vaccination), misdiagnosis, absence of medical care and poor health outcomes in infected people. Knowledge and awareness about the mode of transmission is important for the planning and preventive health education program. Disease control by preventive strategy is more effective than a curative one.

This study was designed to target the non medical students of the University of Kassala by assessing their knowledge and awareness towards HIV and HBV diseases.

\section{Methods}

Cross-sectional study was conducted at the University of Kassala

*Corresponding author: Fatima Abbas Khalid, Tuberculosis Research Center Faculty of Medicine and Health Sciences, University of Kassala, Kassala State, Sudan, E-mail id: fatma_arb_a@yahoo.com

Received January 22, 2013; Accepted February 28, 2013; Published March 05 2013

Citation: Khalid FA, Eltayeb AA, Elbadawi NEE (2013) Awareness and Knowledge of Hepatitis B and HIVIAIDS, Among the University of Kassala Students, Sudan. J AIDS Clin Res 4: 194. doi:10.4172/2155-6113.1000194

Copyright: ( $\odot 2013$ Khalid FA, et al. This is an open-access article distributed unde the terms of the Creative Commons Attribution License, which permits unrestricted use, distribution, and reproduction in any medium, provided the original author and source are credited. 


\begin{tabular}{|c|c|c|c|}
\hline \multicolumn{2}{|c|}{ Mode of transmission of HIV } & \multirow{2}{*}{\begin{tabular}{|l|} 
No \\
291 \\
\end{tabular}} & \multirow{2}{*}{\begin{tabular}{|l|}
$\%$ \\
73.7
\end{tabular}} \\
\hline 1. & Usage of contaminated sharp equipments. & & \\
\hline 2. & Sexual intercourse & 349 & 88.4 \\
\hline 3. & Transfusion of contaminated blood & 284 & 71.9 \\
\hline 4. & Vertically from mother to child & 253 & 64.1 \\
\hline \multicolumn{4}{|c|}{ Signs \& Symptoms of HIV/ AIDS } \\
\hline 1. & Enlargement of lymph nodes & 95 & $24.1 \mathrm{c}$ \\
\hline 2. & Sweat & 80 & 20.3 \\
\hline 3. & General weakness & 245 & 62.0 \\
\hline 4. & Fever & 111 & 28.1 \\
\hline 5. & $\begin{array}{l}\text { Appeared when exposed to opportunistic } \\
\text { microorganisms }\end{array}$ & 99 & 25.1 \\
\hline \multicolumn{4}{|c|}{ Prevention Methods of HIV infection } \\
\hline 1. & Not sharing sharp equipments (razor, needle.) & 230 & 58.2 \\
\hline 2. & Health education & 284 & 71.9 \\
\hline 3. & Investigation of transfused blood & 180 & 45.6 \\
\hline \multicolumn{4}{|c|}{ Mode of transmission of HBV } \\
\hline 1. & Usage of contaminated sharp instruments & 51 & 12.9 \\
\hline 2. & Sexual intercourse & 35 & 8.9 \\
\hline 3. & Transfusion of contaminated blood & 83 & 21 \\
\hline 4. & Vertically from mother to child & 36 & 9.1 \\
\hline \multicolumn{4}{|c|}{ Signs \& symptoms HBV infection } \\
\hline 1. & Fever & 88 & 22.3 \\
\hline 2. & Loss of appetite & 155 & 39.2 \\
\hline 3. & Nausia & 96 & 24.3 \\
\hline 4. & Vomiting & 79 & 20.0 \\
\hline 5. & Jaundice & 112 & 28.4 \\
\hline \multicolumn{4}{|c|}{ Prevention methods of HBV infection } \\
\hline 1. & Vaccination & 167 & 42.3 \\
\hline 2. & Investigation of transfused blood & 107 & 27.1 \\
\hline 3. & Vaccination of neonate & 135 & 34.2 \\
\hline
\end{tabular}

Table 1: Knowledge of Students about the Mode of Transmission, Signs, Symptoms and Prevention of Hepatitis B and AIDS.

from April to July 2011. The study targeted 4000 students who were involved in Bachelor programs at the time of the study. Those students of non medical profession, were from the Faculties of Economics and Administrative Sciences, Computer Sciences and Technology information, and Education which has multiple departments (Biology and Chemistry, Arabic and Islamic Studies, Geography and History). Based on the students' knowledge of $50 \%$, bound error $05 \%$ and confidence interval 95\%. The sample size was 384 .

To assess the students' knowledge and awareness about hepatitis $B$ and AIDS, self administered questionnaire was used. The questionnaire comprised the infective nature of these diseases, infectious agents, mode of transmission, signs and symptoms. The other questions asked were concerned with the availability of vaccine and curability of the diseases, in addition to the preventive methods. Before the distribution of the questionnaire among 455 students, the objective of the study was explained to participants and they were informed that their participation was voluntary. Only 395 questionnaires were fully answered, The correct answers were grouped as: mode of transmission; $0-2=$ poor, $3=$ moderate and $4=$ good, signs and symptom; $0-2=$ poor and $3-4=$ moderate and $5=$ good, prevention $0-1=$ poor, $2=$ moderate, $3=$ good. The data were entered and analyzed using statistical package for social sciences (SPSS) version 16.0 software. Frequencies of variables were calculated and chi squire.

The ethical approval of this study was received from the Research Board Committee, Ministry of Health, Kassala, Sudan.

\section{Results}

A total of 395 students responded to the questionnaire, 185 (46.8\%) were males and $210(53.2 \%)$ were females. Their age ranged from 17 to 35 years with a mean $(20.45 \pm 2.89)$. The students were from different Faculties of the University. 143 (36.2\%) of the students were from the Faculty of Education, 157 (39.7\%) were from the Faculty of Economics and Administrative Sciences and 95 (24.1\%) were from the Faculty of Computer Sciences and Information Technology.

The study revealed the weakness of general knowledge about AIDS and hepatitis B among students. However, they were more knowledgeable about AIDS. Their knowledge about the infectious nature of AIDS was 311 (78.7\%), the infective agent 362 (91.6\%), and the mode of transmission 272 (68.9\%), but they were unaware of the symptoms and preventive measures. The symptoms and the prevention measures were well understood by only $38(09.7 \%)$ and $133(33.7 \%)$ respectively. $79(20 \%)$ of the students understood that HIV had no vaccine (Table 1 ).

Regarding HBV, poor knowledge was found among the students of the University of Kassala. Its communicability which is significantly associated with gender $(\mathrm{P}=0.02)$, was found to be $223(56.5 \%)$, most of them were females (130/ 223) (table 2). The causes of HBV, and its vaccination were known to $110(27.8 \%)$ and $39(09.9 \%)$ of the students respectively. Only $49(12.4 \%)$ of the students were aware of the symptoms of the disease and 15 (3.8\%) had good knowledge of the transmission route, while the prevention methods were known to be $50(12.7 \%)$.

A significant difference was found between the students' knowledge on HIV and HBV concerning the transmission methods $(\mathrm{P}=0.009)$, signs and symptoms $(\mathrm{P}=0.000)$ and prevention methods $(\mathrm{P}=0.000)$. As shown in table 2 the significant difference was found associated with gender in infectious nature of $\operatorname{HBV}(\mathrm{P}=0.020)$, and its signs and symptoms $(\mathrm{P}=0.022)$ and also associated with the route of transmission of AIDS ( $\mathrm{P}=0.033)$.

\begin{tabular}{|c|c|c|c|}
\hline Variables & Male (185) & Female (210) & $P$ value \\
\hline \multicolumn{4}{|l|}{ HIVIAIDS } \\
\hline Infectious nature of AIDS & $150(81.1 \%)$ & $161(76.7 \%)$ & 0.172 \\
\hline Causes of AIDS & $169(91.4 \%)$ & $193(91.9 \%)$ & 0.942 \\
\hline $\begin{array}{r}\text { Route of transmission: } \begin{array}{r}\text { poor } \\
\text { moderate } \\
\text { good }\end{array} \\
\end{array}$ & $\begin{array}{c}63(34.1 \%) \\
18(9.7 \%) \\
104(56.2 \%)\end{array}$ & $\begin{array}{c}60(28.6 \%) \\
14(06.7 \%) \\
136(64.8 \%)\end{array}$ & 0.195 \\
\hline $\begin{array}{r}\text { Signs and symptoms: } \\
\qquad \begin{array}{c}\text { poor } \\
\text { moderate } \\
\text { good }\end{array}\end{array}$ & $\begin{array}{l}151(81.6 \%) \\
17(09.2 \%) \\
17(09.2 \%)\end{array}$ & $\begin{array}{l}169(80.4 \%) \\
20(09.5 \%) \\
21(10.0 \%)\end{array}$ & 0.954 \\
\hline $\begin{aligned} \text { Preventive methods: } & \begin{array}{l}\text { poor } \\
\text { moderate } \\
\text { good }\end{array}\end{aligned}$ & $\begin{array}{l}95(51.4 \%) \\
31(16.8 \%) \\
59(31.9 \%)\end{array}$ & $\begin{array}{l}102(48.6 \%) \\
34(16.2 \%) \\
74(35.2 \%)\end{array}$ & 0.779 \\
\hline \multicolumn{4}{|l|}{ Hepatitis B } \\
\hline Infectious nature & $93(50.3 \%)$ & $130(61.9)$ & 0.020 \\
\hline Causative agent & $49(26.5 \%)$ & $61(29.1 \%)$ & 0.765 \\
\hline $\begin{array}{r}\text { Route of transmission: } \begin{array}{r}\text { poor } \\
\text { moderate } \\
\text { good }\end{array} \\
\end{array}$ & $\begin{array}{l}176(95.1 \%) \\
02(01.1 \%) \\
07(03.8 \%)\end{array}$ & $\begin{array}{c}199(94.8 \%) \\
03(01.4 \%) \\
08(03.8 \%)\end{array}$ & 0.953 \\
\hline $\begin{aligned} & \text { Signs and Symptoms: } \text { poor } \\
& \text { moderate } \\
& \text { good }\end{aligned}$ & $\begin{array}{l}148(80.0 \%) \\
18(09.7 \%) \\
19(10.3 \%)\end{array}$ & $\begin{array}{l}172(81.9 \%) \\
07(03.3 \%) \\
30(14.3 \%)\end{array}$ & 0.022 \\
\hline $\begin{array}{r}\text { Preventive methods: poor } \\
\text { moderate } \\
\text { good }\end{array}$ & $\begin{array}{l}133(71.9 \%) \\
28(15.1 \%) \\
24(13.0 \%)\end{array}$ & $\begin{array}{l}151(71.9 \%) \\
33(15.7 \%) \\
26(12.4 \%)\end{array}$ & 0.976 \\
\hline
\end{tabular}

Table 2: Knowledge and awareness AIDS and hepatitis $B$ regarding the gender of students. 
Citation: Khalid FA, Eltayeb AA, Elbadawi NEE (2013) Awareness and Knowledge of Hepatitis B and HIV/AIDS, Among the University of Kassala Students, Sudan. J AIDS Clin Res 4: 194. doi:10.4172/2155-6113.1000194

\section{Discussion}

This study showed inadequate knowledge about AIDS and hepatitis $B$ but the students were more knowledgeable about AIDS in contrast to HBV. The students understood the communicability of HIV especially in the area of causative agents and the mode of transmission. The same finding was reported in the study held in Pakistan by Khan [11] and in Turkey by Koksal [12]. Awareness regarding HIV/AIDS transmission methods was satisfactory among students, they were aware of transmission of disease through sexual intercourse, usage of unsterile sharp equipments, transfusion of contaminated blood and vertically from mother to child. A similar result was also reported in the study held in Pakistan [13], China [14], Karatchi [15], Kazakhistan [16] and Nigiria [17]. These findings may be attributable to the efforts of HIV/AIDS control program through mass media, lectures and seminars in Sudan. Inadequate knowledge about mode of transmission was reported among black students in the University of Western Cape, South Africa [18].

Regarding HBV, the study revealed that the students had poor knowledge of the infectious nature of the disease, causative agents, mode of transmission, symptoms and preventive measures. The studies which were conducted in Iran [19] and Turkey [20] reported poor knowledge on HBV which are consistent with our results. Other studies in Pakistan [13,21], and Oman [22] reported good knowledge of the disease. The findings of our study may be attributed to the absence of formal school based health education in our country which may be the most important reason for lower knowledge of viral diseases regarding HIV and HBV.

\section{Conclusion}

This study showed that the students had poor knowledge and awareness of viral diseases. As students act as a source of knowledge with their families, more efforts will be needed to develop knowledge and awareness among students, especially for non- biological sciences students to decrease the burden of these diseases.

\section{Authors' contributions}

Fatima A. Khalid and Amna A. Eltayeb and Noureldaim E. Elbadawi designed and initiated the study. Fatima A. Khalid performed the statistical analyses. The authors helped gather and interpret data and write the article. All authors read and approved the final manuscript.

\section{Acknowledgements}

The authors are very grateful to: Prof. Abdalla A. Mohammed and Mohammed A. El-Khedir who reviewed the article and offered valuable feedback, and the students of the University of Kassala who cooperatively participated in the study and helped the Authors to collect the data.

\section{References}

1. Alter MJ (2006) Epidemiology of viral hepatitis and HIV co-infection. J Hepatol 44: S6-9.

2. WHO (2008) Hepatitis B. Fact sheet $N^{\circ} 204$.

3. UNAIDS. World Health Organization, AIDS epidemic data.

4. Delpech V, Gahagan J (2009) The global epidemiology of HIV. Medicine 37: 317-320

5. Mangadu T ( 2010) Awareness and knowledge of HIVIAIDS among female Indian university students in South India and as immigrants in the U.S.- Mexico border region. ETD Collection for University of Texas, EI Paso.
6. Raizada A, Dwivedi S, Bhattacharya S (2011) Hepatitis B, hepatitis C and HIV co-infection at an antiretroviral centre in Delhi. Trop Doct 41: 154-156.

7. Puoti M, Manno D, Nasta P, Carosi G (2008) Hepatitis B virus and HIV coinfection in low-income countries: unmet needs. Clin Infect Dis 46: 367-369.

8. Rodríguez-Méndez ML, González-Quintela A, Aguilera A, Carballo E, Barrio E (2003) Association of HCV and HBV markers in Spanish HIV-seropositive patients in relation to risk practices. Hepatogastroenterology 50: 2093-2097.

9. Monzon OT, Manaloto C, Pizzo P, Masur H (1991) Reluctance/Refusal of Health Care Workers to Provide Service to HIV Infected Patients. Phil J Microbiol Infect Dis 20: 27-31.

10. Sidig A, Mahgoub A, Hussein A (2009) A study of knowledge, attitude, practice towards HIVIAIDS and prevalence of HIVIAIDS among tea sellers women in Khartoum State (April 2004 - May 2005). Sudanese J of Public Health 4: 214 224

11. Khan $\mathrm{H}$, Ishaq $M$, Khan $\mathrm{H}$, Ishaq $\mathrm{T}$ (2008) Knowledge and Attitudes of Students regarding HIV/ AIDS in Peshawar University. RMJ 33: 18-21.

12. Koksal S, Namal N, Vehid S, Yurtsever E (2005) Knowledge and Attitudes towards HIVIAIDS among Turkish students. Infec Dis J Pak 118- 123

13. Khan SJ, Anjum Q, Khan NU, Nabi FG (2005) Awareness about common diseases in selected female college students of Karachi. J Pak Med Assoc 55: 195-198.

14. Albrektsson M, Alm L, Tan X, Andersson R (2009) HIVIAIDS awareness, attitudes and risk behavior among university students in Wuhan, China. Open AIDS J 3: 55-62.

15. Anjum Q, Siddiqui H, Ahmed Y, Rizvi SR, Usman Y (2005) Knowledge of students regarding hepatitis and HIVIAIDS of a private medical university in Karachi. J Pak Med Assoc 55: 285-288.

16. Hansson M, Stockfelt L, Urazalin M, Ahlm C, Andersson R (2008) HIVIAIDS awareness and risk behavior among students in Semey, Kazakhstan: a crosssectional survey. BMC Int Health Hum Rights 8: 14.

17. Gugnani A, Ukeje MA (1993) A study on existing knowledge about AIDS among undergraduates of a Nigerian University. J Commun Dis 25: 52-56.

18. Nicholas LJ, Tredoux C, Daniels P (1994) AIDS knowledge and attitudes towards homosexuals of black first-year university students: 1990-1992. Psychol Rep 75: 819-823.

19. Ghahramani F, Mohammadbeigi A, Mohammadsalehi N (2006) A Survey of the Students' Knowledge about Hepatitis in Shiraz University of Medical Sciences. Hepatitis Monthly 6: 59-62.

20. van der Veen YJ, Voeten HA, de Zwart O, Richardus JH (2010) Awareness, knowledge and self-reported test rates regarding Hepatitis B in Turkish-Dutch: a survey. BMC Public Health 10: 512.

21. Razi A, Rehman R, Naz S, Ghafoor F, Aman Ullah Khan M (2010) Knowledge attitude and practices of University students regarding hepatitis $B$ and C. ARPN Journal of Agricultural and Biological Science 5: 38-49.

22. Al-Jabri AA, Al-Adawi S, Al-Abri JH, Al-Dhahry SH (2004) Awareness of hepatitis $B$ virus among undergraduate medical and non-medical students. Saudi Med J 25: 484-487. 